\title{
Effects of the povidone-iodine (PVPI) in treatment of bacterial peritonitis induced in rats ${ }^{1}$
}

\author{
Eficácia do polivinilpirrolidona-iodo (PVPI) no tratamento da peritonite bacteriana em ratos
}

\author{
Ivana Duval de AraujoI, Giovanni Cezar Xavier Grossi" ${ }^{I}$, Simone Odília Fernandes Diniz ${ }^{\mathrm{II}}$, Tarcizo Afonso Nunes ${ }^{\mathrm{I}}$, Eduardo \\ Ângelo Braga ${ }^{\mathrm{IV}}$, Valbert Nascimento Cardoso ${ }^{\mathrm{V}}$
}

${ }^{\mathrm{I}} \mathrm{PhD}$, Associate Professor, Medical School, UFMG, Minas Gerais, Brazil.

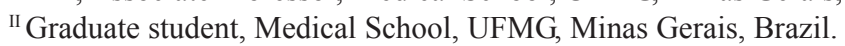

III PhD, Assistant Professor, Pharmacy School, UFMG, Minas Gerais, Brazil.

Iv Fellow Master degree in Surgery, Medical School, UFMG, Minas Gerais, Brazil.

v PhD, Associate Professor, Pharmacy School, UFMG, Minas Gerais, Brazil.

\begin{abstract}
Purpose: To evaluate the effectiveness of the use of the povidone-iodine (PVI) added to the liquid of wash of the peritoneal cavity in the reduction of bacterial absorption and in the remainder non-phagocyted bacteria in the circulating blood of rat. Methods: Thirty four Wistar females rats were used, distributed in the following groups: $\mathrm{n}(\mathrm{n}=10)$, non-treated; $\mathrm{B}(\mathrm{n}=9)$, wash of the peritoneal cavity with solution of PVI to $1 \%$ in saline solution; $\mathrm{C}(\mathrm{n}=15)$, wash of the cavity with saline solution. After anesthesia, it was made intraperitoneal infusion of solution of Escherichia coli labeled with $99 \mathrm{mTc}$ containing $10^{8} \mathrm{CFU} / \mathrm{ml}$. After 40 minutes, it was made the treatment, in the group A, manipulation of the viscera; in the group B, irrigation of the peritoneal cavity with warm solution of $1 \%$ PVPI to $37,5^{\circ} \mathrm{C}$, and in the group $\mathrm{C}$ irrigation with warm saline $\left(37,5^{\circ} \mathrm{C}\right)$. After 15 minutes of the treatment, blood samples and fragments of liver, spleen and lung was obtained for count of the radioactivity, and animals killed by abdominal aorta section. There were determined the bacterial absorption index and the remainder index in the bloodstream. Results: Of the total of bacteria infused in the peritoneum, there was absorption of $0,92 \%(0,14 \%$ to $2,13 \%)$ in the animals of the group A (controls), $0,49 \%(0,18 \%$ to $0,71 \%)$ after use of topical PVPI (group B) and $0,80 \%(0,04 \%$ to $3,8 \%)$ after wash with saline solution (group C). There was significant reduction of the absorption when compared the treated animals with PVPI and the controls $(\mathrm{p}=0,003)$. Of the total of bacteria absorbed for the circulatory current, the percentile amount of bacteria non-phagocyted in the outlying blood was of $2,9 \%(1,1 \%$ to $17,7 \%)$ in the control group, $15,2 \%(8,3 \%$ to $21,4 \%)$ in those treated with PVPI (group B) and 6,9\% (0,8\% to 29,7\%) after wash with saline solution (group C), with difference among controls and treated with PVPI $(\mathrm{p}=0,01)$. Conclusion: The wash of the cavity peritoneal of mice with solution containing PVPI showed to be capable to reduce the absorption of bacteria by peritoneum of rat; however it seems to interfere with the function of the phagocytic cells for the observation of the increase of viable bacteria in the outlying blood of those animals.

Key words: Peritonitis. Peritoneal Lavage. Povidone-Iodine. Rats.
\end{abstract}

\section{RESUMO}

Objetivo: Avaliar a eficácia do uso do polivinilpirrolidona-iodo (PVPI) acrescido ao líquido de lavagem da cavidade peritoneal na redução da absorção bacteriana e no remanescente bacteriano não fagocitado no sangue periférico de ratos. Métodos: Estudou-se 34 ratos Wistar fêmeas, distribuídos aleatoriamente nos seguintes grupos: controle $(n=10)$, nenhum tratamento; PVPI ( $n=9)$, lavagem da cavidade peritoneal com solução de PVPI a $10 \%$ em solução salina; salina $(n=15)$, lavagem da cavidade com solução salina. Após anestesia, fez-se inoculação intraperitoneal de solução de Escherichia coli marcadas com $99 \mathrm{mTc}$ contendo $10^{8} \mathrm{UFC} / \mathrm{ml}$. Após 40 minutos, realizou-se o tratamento que foi, no grupo controle, manipulação das vísceras; no grupo PVPI, irrigação da cavidade peritoneal com solução de PVPI aquecido a $37,5^{\circ} \mathrm{C}$ na concentração de $1 \%$, e no grupo salina irrigação com solução salina aquecida a $37,5^{\circ} \mathrm{C}$. Após 15 minutos do tratamento, os animais foram mortos por secção da aorta abdominal e colhidas amostras do sangue, do fígado, do baço e do pulmão para contagem da radioatividade. Foram determinados o índice de absorção bacteriano e o índice de remanescente no sangue periférico. Resultados: Do total de bactérias inoculadas no peritôneo, houve absorção de $0,92 \%(0,14 \%$ a $2,13 \%)$ nos animais do grupo controle, $0,49 \%(0,18 \%$ a $0,71 \%)$ após uso do PVPI tópico e $0,80 \%(0,04 \%$ a 3,8\%) após lavagem com solução salina. Houve redução significativa da absorção quando comparados os animais tratados com o PVPI e os controles não tratados ( $\mathrm{p}=0,03$ ). Do total de bactérias absorvidas para a corrente circulatória, o percentual de bactérias não fagocitadas presentes no sangue periférico foi de $2,9 \%$ (1,1\% a $17,7 \%)$ nos animais controle $15,2 \%(8,3 \%$ a $21,4 \%)$ naqueles tratados com PVPI e $6,9 \%(0,8 \%$ a $29,7 \%)$ após lavagem com solução salina, com diferença entre os animais controle e os tratados com PVPI $(p=0,01)$. Conclusão: A lavagem da cavidade peritoneal de camundongos com solução contendo PVPI mostrou ser capaz de reduzir a absorção de bactérias pelo peritôneo de ratos, entretanto associou-se a aumento de bactérias viáveis no sangue periférico desses animais.

Descritores: Peritonite. Lavagem Peritoneal. Povidona-Iodo. Ratos.

${ }^{1}$ Research performed at Laboratory of Surgical Research, Medical School and Radioisotopes Laboratory, Pharmacy School, Federal University of Minas Gerais (UFMG), Brazil. 


\section{Introduction}

The secondary bacterial peritonitis is an important cause of sepsis and death in surgical practice. The pathophysiology of this disease involves the activation of local and systemic inflammatory mechanisms in presence of an intra-abdominal infectious focus. Cellular and humoral components as well cytokines and acute phase proteins act together in order to containing the infection ${ }^{1}$. The exacerbation of these inflammatory response, with activation of cellular elements as macrophages and mast cells, and systemic liberation of reactive products of oxygen and cellular mediators of the inflammation compromise the economy of the organism, taking the even the bankruptcy. In function of that exacerbated inflammatory response, the mortality is high $^{2}$

When secondary peritonitis occurs rapid bacterial proliferation is capable to affect the peritoneal response. The peritoneal irritation provoked by the gross contamination associated to the levels of cytokines cause overture of endothelial junctions, with possibility of the passage of bacteria into systemic circulation. In this case, the integrity of the mononuclear phagocytic system becomes necessary to phagocytosis and inactivation of circulating bacteria ${ }^{2,3}$.

In the approach of the peritoneal cavity, is important the control of the infectious focus, and mechanical removal of the gross contamination. The lavage of peritoneal cavity is made in order to increase the index of mechanical removal of particles as fibrin and septic clots and, despite largely used, is not a consensus. It was demonstrated that the vasodilatation caused by the warm saline solution would promote cellular damage, increase of the inflammatory response, increase of macrophage activation in lesion area, loss of macrophagic functional capacity and is associated to increase of index of omental absorption of bacteria. However, it was observed that $97 \%$ of general surgeons used the abdominal lavage, and most opts for the use of the saline solution in enough amounts so that solution presented cleans ${ }^{4}$.

The use of antiseptics or antimicrobials added to the liquid of lavage is not a consensus, existing controversy about the relationship of applicability and effectiveness, because seemingly it would not present benefits. Several studies have been demonstrating that there was reduction of the mortality, in mice, after the institution of the therapeutics of peritoneal lavage with solutions containing antiseptics as povidone-iodine (PVI), results that were not corroborated by other authors ${ }^{5,6}$.

Part of the discussion on the use of the peritoneal lavage with or without antiseptics it goes by the access need to a therapeutics capable to reduce the bacterial population of the peritoneum without to affect its function or to allow larger passage of bacteria for the circulatory bloodstream, or to have any cytotoxic effect capable to affect the function of the phagocytic cells.

This study was conducted in order to measure the index of absorption of bacteria from peritoneal cavity and the percentile of non phagocyted bacteria in the bloodstream in rats with induced secondary peritonitis, treated with peritoneal lavage with saline solution or $1 \%$ PVI.

\section{Methods}

This work was conducted according International Guide of Use of Laboratory Animals. There were studied 34 females Wistar rats with age between 2 and 3 months, and weight between 200 and $250 \mathrm{~g}$. The animals were obtained from Institute of Biological Sciences, Federal University of Minas Gerais (UFMG), and staying in observation period in ambient with natural climatization, mechanical exaustion and natural ventilation, and day/night natural cycles. Water and food (Labina ${ }^{\circledR}$, Purina) were offered for animals ad libitum.

The animals were distributed in the following experimental groups:

Control $(n=10)$, infusion of bacterial suspension in the peritoneal cavity, without subsequent treatment;

PVI $(n=9)$, infusion of bacterial suspension in the peritoneal cavity followed by the lavage with $1 \%$ PVI added to warm saline solution;

Saline $(n=15)$, infusion of bacterial suspension in the peritoneal cavity followed by the lavage with warm saline solution.

The bacterial suspension infused into peritoneal cavity was obtained from a sample of standard Escherichia coli that, after growth in plate, was marked with $99 \mathrm{mTecnetium}(99 \mathrm{mTc})$ as technique described by Diniz ${ }^{7}$. Concisely, aliquots of $2 \mathrm{ml}$ of the bacterial suspension were incubated to $37^{\circ} \mathrm{C}$ with $580 \mu \mathrm{M}$ of stannous chloride with $\mathrm{pH} 7.0$ for 10 minutes. Soon after, it was added between 15,0 and $74,0 \mathrm{MBq}$ of $99 \mathrm{mTc}$ to each tube, staying the incubation for 10 minutes to $37^{\circ} \mathrm{C}$. After centifugation, aliquots of $100 \mu \mathrm{l}$ of the supernatant and of the precipitate were retired for determination of the marcation index. Them, the number of units forming of colonies was determined by means nefelometry and saline solution added to a final concentration of $10^{8} \mathrm{UFC} / \mathrm{ml}$. The inocula were prepared through the aspiration of $0.25 \mathrm{ml}$ of suspension into a syringe, the radioactive reading of each syringe, before and after each infusion, turning therefore known the total amount of radioactivity in the suspension that was infused in the animals. The inocula were infused through peritoneal puncture after anesthesia with intramuscular injection of ketamine $(100 \mathrm{mg} / \mathrm{Kg})$ associated the xylazine $(50 \mathrm{mg} / \mathrm{Kg})$. After 40 minutes, the abdomen was opened and treated accordingly the different groups described.

In the animals of the control group it, it was made laparotomy, inspection of the abdominal cavity, aspiration of the peritoneal liquid, manipulation of the intestinal loops and closure of abdominal wall. In the animals of the group PVI, was made aspiration of the peritoneal liquid followed by the lavage with warm $\left(37.5^{\circ} \mathrm{C}\right) 1 \%$ PVI three times, and closure of abdominal wall. In the saline group, it was made aspiration of the peritoneal liquid, lavage with warm $\left(37.5^{\circ} \mathrm{C}\right)$ saline solution three times, and used for irrigation of the cavity by three times, and closure of abdominal wall.

After 15 minutes interval, during which the animal stayed under the anesthetic agent's effect, the abdominal cavity was opened. The process of phagocytic study was the same standardized in our laboratory ${ }^{8}$. Three milliliters of blood was collected by puncture of the vena cava to obtain samples for 
radioactive counts. The animals were then sacrificed by section of the abdominal aorta and exsanguinated, and fragments were obtained from the left lobe of the liver and the inferior lobe of the right lung. The spleen was fully removed. The samples were fixed in $10 \%$ formalin and placed in the tubes of a gamma counter. Radioactivity counts were performed on the fragments, which were also weighed. The radioactive of total blood sample was also counted in the gamma chamber, and this data used in the calculation of the distribution of the bacteria in the organs and calculation of the bacterial absorption. Soon after, the blood samples were left in rest by one hour and retired a sample of one milliliter of serum for radioactive count, eliminating with that the reading of the $99 \mathrm{mTc}$-labelled bacteria into neutrophils. That was the data used in the calculation of the non-phagocyted remainder in the bloodstream.

First, we determine the participation of each organ in phagocytosis, by means the proportional radioactivity per gram of organ tissue. It was made by the proportional calculation based on the division of fragment radioactivity by fragment weight. The proportional radioactivity of each sample was then calculated considering the radioactivity obtained by the sum of the individual radioactivity per gram of liver, spleen, and lung; and in a $\mathrm{ml}$ of blood to be $100 \%{ }^{9}$. Thus, the proportional radioactivity of the liver, for example, was the radioactivity per gram of liver tissue multiplied by $100 \%$ and divided by the radioactivity per gram of liver, lung, spleen and blood added together (see formula below). This permitted us to obtain the degree of uniform participation of each organ in the phagocytosis of systemically infused bacteria.

$$
\text { Phagocytosis }=\frac{c p m(g) / \text { organ } \cdot \text { or } \cdot \operatorname{cpm}(m l) / \text { blood }}{\sum c p m(g) / \text { organ }+c p m(m l) / \text { blood }}
$$

When:

Cpm(g)/organ or cpm( $\mathrm{ml})$ corresponded to the radioactive reading of the fragment of the liver multiplied by the medium weight of $8.0 \mathrm{~g}$, or radioactivity of the spleen multiplied by 0.9 or radioactivity of the fragment of the lung multiplied by 1.2

$\Sigma c p m(g) / o r g a n+c p m(m l) /$ corresponded to the radioactive reading of the fragment of the liver multiplied by the medium weight of $8.0 \mathrm{~g}$ added to the radioactivity of the spleen multiplied by $0.9 \mathrm{~g}$, added the radioactivity of the fragment of the lung multiplied by $1.2 \mathrm{~g}$, added the radioactivity in the sample of blood multiplied by $5 \mathrm{ml}$.

$$
\text { Cpm - count per minute }
$$

For calculation of bacterial remainder, it was made the subtraction, of the total blood, of the percentile of radioactive reading of the serum, with that settling down the percentile of labeled bacteria free in the bloodstream (percentile of nonphagocyted bacterias after 40 minutes). The calculation of the bacterial absorption was obtained by the subtraction, of the total radioactivity infused previously known, of the total radioactivity in the organs, according to the formula below.

$$
\text { Absorption }=\mathrm{cpm} \text { infunded }-\Sigma \mathrm{cpm} \text { in total organs }+ \text { blood }
$$

When:

$\Sigma c p m$ in total organ + blood corresponded to the total radioactive in liver, spleen, lung and blood
The values of the bacterial absorption, remainder non phagocyted bacteria in bloodstream and bacteria (phagocyted or not) in the were compared among the animals of the groups control, PVI and saline through Kruskall-Wallis test, and considered differences for $\mathrm{p}<0.05$.

\section{Results}

The amount of bacteria absorbed by the peritoneum was $0.92 \%(0.14 \%$ to $2.13 \%)$ in control group, $0.80 \%(0.04 \%$ to $3.8 \%)$ in saline group and $0.49 \%(0.18 \%$ to $0.71 \%)$ in PVI group. There was significant difference when the animals control was compared with those treated with PVPI ( $\mathrm{p}=0.03)$, as see in Figure 1.

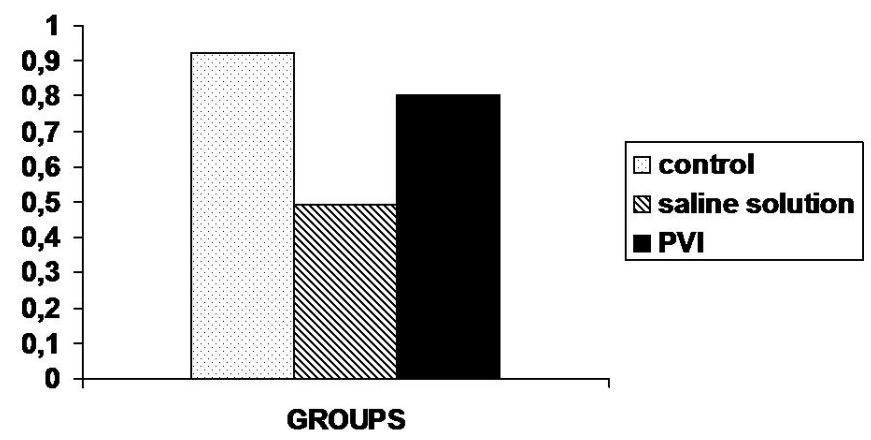

FIGURE 1 - Percentile of absorbed bacteria by peritoneum in rats non-treated (control) or treated with saline solution or PVI $* \mathrm{p}=0.03$

Being considered the amount radioactivity present the in liver, spleen, lung and blood as $100 \%$ (total) in the organism, in the control group the hepatic fagocitosis was of $9.6 \%(3.0 \%$ to $52.8 \%$ ), the splenic was of $76.1 \%(12.9 \%$ to $91.1 \%)$, the pulmonary was $3.8 \%(1.3 \%$ to $70.3 \%)$ and the remainder non phagocyted in the blood was of $2.9 \%$ (1.1\% to $17.7 \%)$. The greatest amount of labeled bacteria was found in the spleen, followed by the liver, coming the pulmonary and last the remainder of non-phagocyted bacteria in the bloodstream (Figure 2).

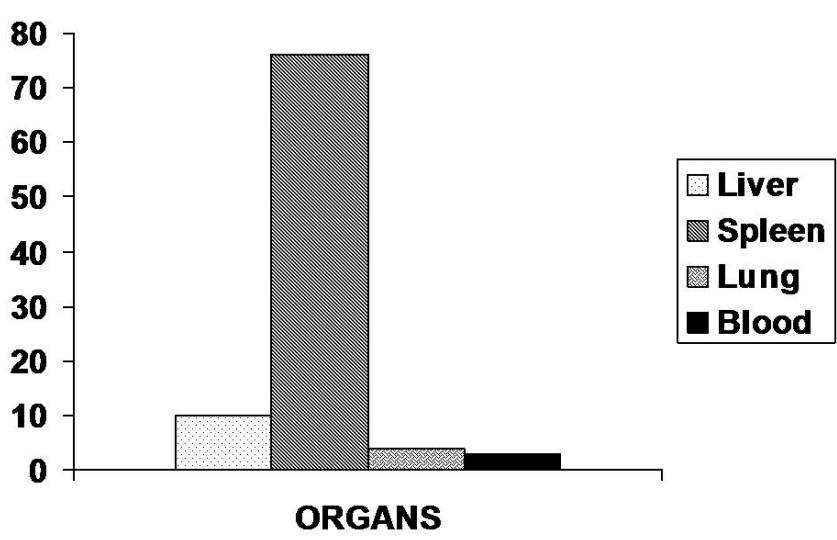

FIGURE 2 - Percentile of bacteria phagocyted by hepatic, splenic, pulmonary MPS and non-phagocyted remainder in bloodstream in non-treated rats (controls) 
In the saline group, the hepatic phagocytosis was of $16.7 \%(1.4 \%$ to $63.2 \%)$, the splenic was of $61.1 \%(23.2 \%$ to $87.3 \%)$, the pulmonary was $6.4 \%(0.8 \%$ to $57.5 \%)$ and the remainder nonphagocyted in the bloodstream was $6.9 \%(0.8 \%$ to $29.7 \%)$. The distribution, for decreasing order of phagocytosis, was the splenic, followed by the hepatic, coming the remainder non-phagocyted in bloodstream and, finally, the pulmonary phagocytosis (Figure 3).

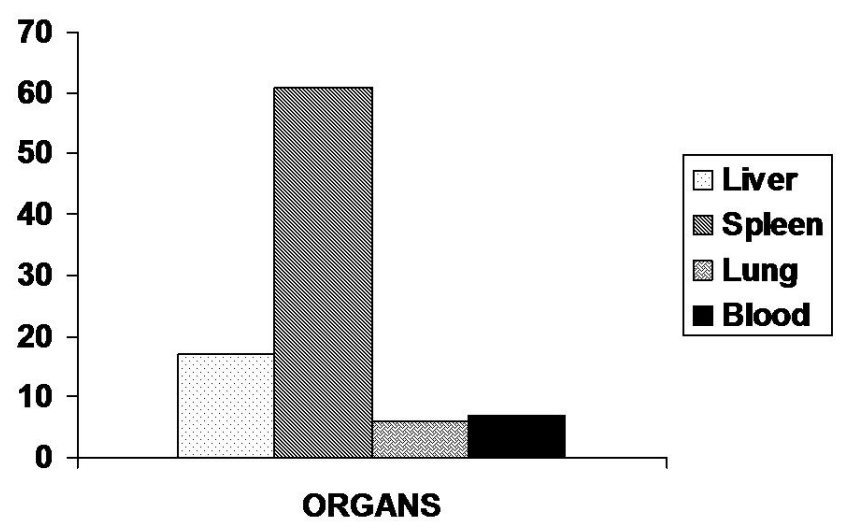

FIGURE 3 - Percentile of bacteria phagocyted by hepatic, splenic, pulmonary MPS and non-pagocyted remainder in bloodstream in saline-treated rats

In the group treated with PVI, the hepatic phagocytosis was $22.9 \%$ (15.8\% to $35.7 \%$ ), the splenic $51.3 \%$ (41.9\% to $74.1 \%)$, the pulmonary $4.2 \%(1.8 \%$ to $10.6 \%)$ and the remainder nonphagocyted $15.2 \%(8.3 \%$ to $21.4 \%)$. Also in that group it was more important the splenic phagocytosis, followed by the hepatic phagocytosis, coming the non-phagocyted remainder in bloodstream and, finally, the pulmonary phagocytosis (Figure 4).

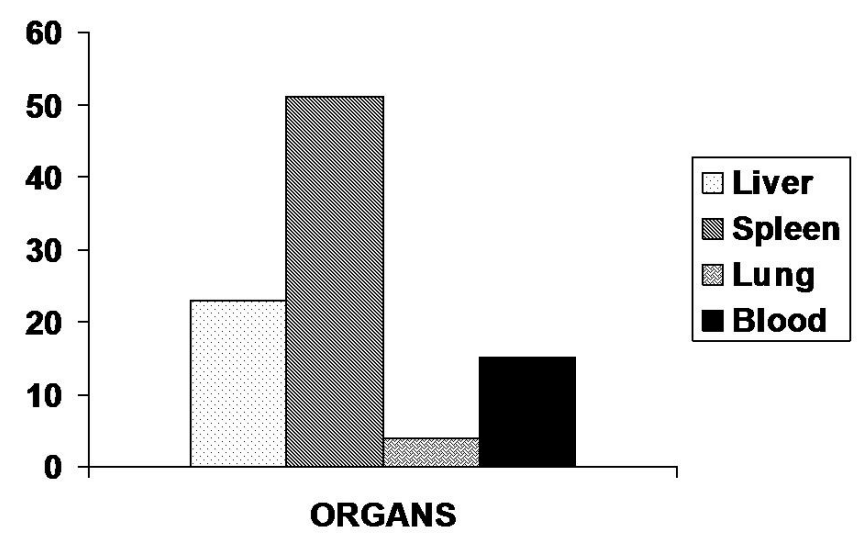

FIGURE 4 - Percentile of bacteria phagocyted by hepatic, splenic, pulmonary MPS and non-phagocyted remainder in bloodstream in PVI treated rats
The hepatic phagocytosis was higher in the group treated with PVI and lowest in the control group, the higher splenic phagocytosis in the group control and smaller in the group treated with PVI, and the pulmonary phagocytosis was lowest in the group control and higher in the group treated with saline solution. There was not significant difference in none of those parameters.

The remainder non-phagocyted bacteria in the bloodstream was lowest in the group control and higher in the group treated with PVI, with significant difference $(\mathrm{p}=0.01)$, as see in Figure 5.

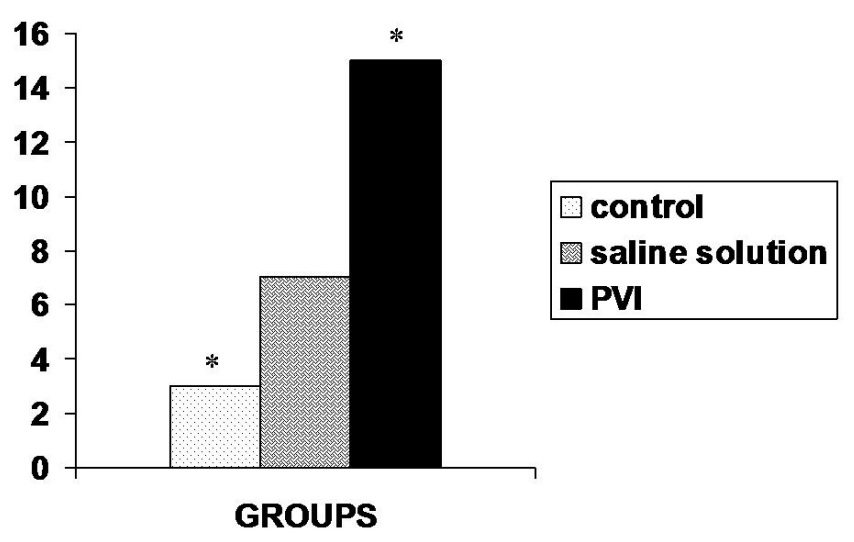

FIGURE 5 - Remainder of bacteria not phagocyted in bloodstream in rats of control group, treated with saline solution or treated with PVI.

$* \mathrm{p}=0.01$

\section{Discussion}

The peritoneal infections are important cause of death in surgical practice and in intensive care units ${ }^{10}$. The factors that influence the gravity of the disease is the individual's immunocompetency, the bacterial virulence and others. Among the factors related to the individual's immunocompetency, the intact function of the peritoneal macrophages is indispensable in the recognition and location of the intra-abdominal infectious processes, what is made through the generation of appropriate inflammatory response ${ }^{11}$. The variation in the indexes of toxins in cellular surface versus the membrane receptors is intimately related with the capacity of location of the process, and inhibition of the absorption of bacteria and toxins ${ }^{3}$.

To improve the understanding of the pathophysiology of the peritonitis and to evaluate the effectiveness of new therapeutics, several techniques of experimental induction of peritonitis were developed, from the initial studies in mice. The model more used is the ligation and puncture of the cecum, that have the advantage of promoting similar pathophysiology of the secondary peritonitis in human beings, with peritoneal irritation, necrosis, presence of great amount of citokines and continuous leak of intestinal content to abdomen ${ }^{12}$. However, it can present great variability of responses, once the inflammatory response and the mortality depends on the diameter of the cecal perforation. Besides, the model with ligation and puncture of the cecum does not allow the amount of bacteria present in the peritoneal cavity. 
It is a good model for evaluation of the systemic inflammatory response and mortality, but it is not effective for study of the absorption of bacteria and products or phagocytic function of mononuclear phagocytic cells system or polymorphonuclear cells.

The inoculation of bacterial suspensions or bacterial clot inoculated into peritoneal cavity, with pre-defined type and amount of bacteria, have as disadvantage of not to provoke exuberant peritoneal and systemic reaction. However, for studies when the amount of bacteria should be monitored, as in this work, the model of infusion of bacterial suspension has larger applicability and reprodutibility. In this study, it was made the induction of the peritonitis through the infusion of a bacterial innocula by intraperitoneal route, in the same concentration in all the animals.

The studies made in rodent models cannot be freely applied in human beings, once those animals present different suscebility to gram negative infections and systemic endotoxemia, reason for the which studies of the effectiveness of treatments based on the mortality cannot be extrapolated for the human being. However, when studied the response of specific cellular types, more necessary evaluation can be had from the response to the same therapeutics used in human beings.

The basic principles in the local treatment of the secondary bacterial peritonitis are fluid reposition, repair of the lesion and cleaning of the collections. To aid the immunitary function in abdominal sepsis, the most effective method of to treat the infectious focus, and to reduce the mortality in the diffuse peritonitis, appears is the exhausting lavage of the peritoneal cavity, that improves the cleaning of the cavity, facilitates the aspiration of pollutants and reduces the concentration of bacteria and other substances ${ }^{13}$. The most preferred method to cleaning the abdominal cavity is the use of saline solution, but peritoneal lavage with antiseptics or antimicrobials added to saline solution are sometimes used.

The lavage of peritoneal cavity with saline solution is used in order to reduce the bacterial contamination, and to remove clot, feces and necrotic tissue. These results are controversial because there was not evidence that the peritoneal lavage have any effect on the mortality or index of postoperative complications. It was observed that, after lavage of the cavity with saline solution, there is compromising of the peritoneal cellular defense, with reduction of the inflammatory cells, and reduction and blockade of the function of the peritoneal macrophage ${ }^{13,14}$. According to our data, the lavage with saline solution reduced, but not significantly, the absorption of bacteria.

The lavage of the abdominal cavity with solutions containing antimicrobials also shows controversial results. Although in some studies the results of these therapeutics showed improve in postoperative course, others did not evidenced benefits related to its use. Several arguments exist against the use of the antimicrobials in the liquid of lavage, as the fact that these therapeutics does not eliminate the bacteria of the cavity, presents toxicity, promotes not controlled absorption of the drug, favors the formation of adherences, increases the endotoxin production and inhibits the antibacterial activity of neutrophils ${ }^{13}$.

The use of antiseptic added to the peritoneal liquid of lavage can produce toxic effects, may be due s metabolic acidosis in $\operatorname{dogs} s^{15}$. Locally, it was observed that the use of PVI reduced the percentile of neutrophils in peritoneal cell population ${ }^{16}$, and it is capable to cause serious damages to the peritoneum, mainly in presence of peritonitis ${ }^{13}$.

According to data of this study, there was more important reduction of the absorption of bacteria in PVI treated group, probably due to increase in bacterial death an lisis, or smaller damage to peritoneal cells ${ }^{6}$. However, we observed that systemic response after peritoneal PVI lavage suggested some cell damage, because, despite decrease in peritoneal absorption of bacteria, there was larger amount of non phagocyted bacteria in bloodstream, what could be cause sepsis and SIRS. Other authors did not verify any bactericidal effect and none superior effect to the lavage with PVI added to saline solution about the mortality of mice ${ }^{5,15}$. Others authors that defend its use, showed that the use of PVI in peritoneal lavage liquid reduced the mortality of rats and mice with induced peritonitis ${ }^{13}$, increasing the mechanisms of defense of the peritoneum.

The macrophages are defense cells that exercise fundamental role in the specific and not specific immunitary response ${ }^{11}$. The intraperitoneal infusion of bacteria, as used in this study, induces a slow and constant bacteremia, and the blood count of bacteria after intraperitoneal infusion of bacteria represents the balance among the continuous absorption of the bacteria present in the peritoneal cavity and the removal of those microorganisms for the cells of hepatic, splenic and pulmonary mononuclear phagocyte system (MPS). When persistent bacteremia occurs, as observed in this work in PVI treated group, it should be thought about the possibility of persistence of microorganisms in the peritoneal cavity, reduction of the depurating capacity of MPS or incapacity of lisis by circulating phagocytic cells.

The inhibition of the immunitary system that happens in diffuse peritonitis can be secondary to increase of absortive function of the peritoneum. The inflammatory reaction provoked by the bacterial load would increase the absorption of the intra-abdominal content, rich in bacteria and endotoxins, as sees in experimental models. Probably, in the acute peritonitis, the absorption of bacterial products by omentum is followed by your rapid presence in the bloodstream ${ }^{17}$, due to increase in vascular permeability that happen for the action of vasodilators prostaglandins like PGI2 and PGE2, secreted by the activated macrophage ${ }^{11}$.

Among the complications of the peritonitis, the failure of terminal organs, like the lungs, occurs in about $74 \%$ of the patients, and is one of the principal death causes in patients with peritonitis ${ }^{18}$. Some authors suggest that inflammatory diseases, as the peritonitis, can cause increase of the oxidative activity in the lung, resulting in peroxidation of the membrane, and that, in the peritonitis, there are persistent migration of neutrophils for the lung mediated by action of citocikines secreted by activated macrophages, with consequent alveolocapillar lesion and liberation of oxygen free radicals. The clinical result of that peroxidation is edema that may be due a role in increase in microvascular permeability. The neutrophils influx to the lung, in the animal experiments, is related with the amount of bacteria infused into peritoneal cavity ${ }^{19,20}$. The results of our study, indicating increase of the presence of bacteria in the lung, can suggest, indirectly, an increase in macrophage lung activation, what done a greather contribution to inflammatory response with induction to polimorphonuclear influx for the lung. These cells induce tissue damage for the production of toxic metabolites of oxygen able to harm the alceolocapillar membrane ${ }^{21}$. 


\section{Conclusion}

The lavage of peritoneal cavity with PVI did not demonstrate to be a reliable therapeutics in the local control of the peritonitis, once, parallel to the reduction of the bacterial absorption, there was significantly larger bacteremia in that group.

\section{References}

1. Kreimer F, Aguiar JLA, Castro CMB, Lacerda CM, Reis T, Lisboa Jr R. Resposta terapêutica e inflamatória de ratos com peritonite secundária submetidos ao uso tópico de ampicilina/sulbactan. Acta Cir Bras. 2005;20(Suppl 1):31-9.

2. Fukatsu K, Saito H, Han I, Inoue T, Furukawa S, Matsuda T, Ikeda S, Yasuhara H, Muto T. Concomitant increase in neutrophil adhesion to inflammatory peritoneum and remote organs during peritonitis. J Surg Res. 1999;81(2):156-63.

3. Hart PH, Jones CA, Finlay-Jones JJ. Peritoneal macrophages during peritonitis. Phenotypic studies. Clin Exp Immunol. 1992;88(3):484-91.

4. Seiler CA, Brügger L, Forssmann U, Baer HU, Büchler MW. Conservative surgical treatment of diffuse peritonitis. Surgery 2000;127(2):178-84.

5. Oguz M, Bektemior M, Dulger M, Yalinj R. Treatment of experimental peritonitis with intraperitoneal povidine-iodine solution. Can J Surg. 1988;31(3):169-71.

6. Abbasoglu O, Sayek I, Hascelik G. Effect of povidone-iodine lavage on peritoneal defence mechanism in rats. Eur J Surg. 1993;159(10):521-4.

7. Diniz SOF, Duval-Araujo I, Machado LAS, Cardoso VN. Evaluation of the phagocitary capacity of the mononuclear system in an experimental model of obstructive jaundice employing Tc-99m Escherichia coli. Braz Arch Biol Tech. 2005;48 (1):37-43.

8. Duval-Araujo I, Sarmiento MAG, Grossi GCX, Simal CJR, Cardoso VN, Diniz SOF. Pulmonary phagocyte depression induced by an acid or alkaline solution in a rat model of peritonitis. Surg Infect. (Larchmt) 2007;8 (6):599-604.

9. Duval-Araujo I, Petroianu A, Simal CJR, Souza IKF, Oliveira Neto JE, Brandão Júnior PS. Phagocyte inhibition in the rat liver, spleen and lung. Acta Cir Bras. 1994;9 (2):169-71.
10. Billing AG, Frohlich D, Konecny G. Local serum application: restoration of sufficient host defense in human peritonitis. Eur J Clin Invest. 1994, 24(1):28-35.

11. Oghiso Y, Yamada Y, Shibata Y. Exsudation of proliferative macrophages in local inflammation in the peritoneum. J Leuk Biol. 1992;52(4):421-4. 12. Bicalho PRR, Lima LB, Alvarenga DG Duval-Araujo I, Nunes TA, Reis FA. Clinical and histological responses to laparoscopically-induced peritonitis in rats. Acta Cir Bras. 2008;23(5):456-61.

13. Rosman C, Westerveld GJ, Kooi K, Bleichrodt RP. Local treatment of generalized peritonitis in rats. Effects on bacteria, endotoxin and mortality. Eur J Surg. 1999;165 (11):1072-9.

14. Whiteside OJ, Tytherleigh MG Thrush S, Farouk R, Galland RB. Intra-operative peritoneal lavage - who does it and why? Ann R Coll Surg Engl. 2005;87 (4):255-8.

15. Lores ME, Ortiz JR Rossello PJ. Peritoneal lavage with povidoneiodine solution in experimentally induced peritonitis. Surg Gynecol Obstet. 1981;153 (1):33-8.

16. Celdran A, Inarrea P, Fernandez J. Neutrophil dynamics in abdominal cavity of peritonitic rats treated with antiseptics. Int Surg. 1993;78(4):354-6. 17. Steinmüller M, Srivastava M, Kuiel WA, Christman JW Seeger W, Welte T, Lohmeyer J, Maus UA. Endotoxin-induced peritonitis elicits monocyte immigration into the lung: implications on alveolar space inflammatory responsiveness. Resp Res. 2006;7(2):30-7.

18. Vincent JL, Puri VK, Carlson RW, Weil MH. Acute respiratory failure in patients with generalized peritonitis. Resuscitation. 1983;10 (4):283-90.

19. Mercer-Jones MA, Heinzelmann M, Peyton JC, Wickel DJ, Cook M, Cheadle WG. The pulmonary inflammatory response to experimental fecal peritonitis: relative roles of tumor necrosis factor-alpha and endotoxin. Inflammation. 1997;21(4):401-17.

20. Peralta JG, Barnard ML, Turrens JF. Characteristics of neutrophil influx in rat lungs following fecal peritonitis. Inflammation. 1993;17 (3):263-71. 21. Malavyia R, Abraham SN. Role of mast cell leukotrienes in neutrophil recruitment and bacterial clearance in infectious peritonitis. J Leukoc Biol. 2000;67(6):841-6.

\section{Correspondence:}

Ivana Duval-Araujo

Rua Bento Mendes Castanheira, 121/102

31260-270 Belo Horizonte - MG Brazil

idaraujo@medicina.ufmg.br

Received: January 18, 2010

Review: March 15, 2010

Accepted: April 19, 2010

\section{How to cite this article}

Araujo ID, Grossi GCX, Diniz SOF, Nunes TA, Braga EA, Cardoso VN. Effects of the povidone-iodine (PVPI) in treatment of bacterial peritonitis induced in rats. Acta Cir Bras. [serial on the Internet] $2010 \mathrm{July}-\mathrm{Aug} ; 25(4)$. Available from URL: http://www.scielo.br/acb 